\title{
Self-serving performance attributions in the letters to shareholders: A longitudinal case study
}

\author{
Maria-Silvia Săndulescu ${ }^{\mathrm{a}, 1}$ \\ ${ }^{a}$ The Bucharest University of Economic Studies, Romania
}

\begin{abstract}
Research Question: How are post-privatization corporate narratives used by the companies in framing their financial performance? Motivation: This research departs from previous literature that scrutinized the use of narratives in the context of corporate privatizations (Craig \& Amernic, 2008). The study adopts a socialpsychology perspective on impression management (Leary \& Kowalski, 1990), drawing on the attributional repertoire developed by Aerts (2005) in order to analyse the causal explanations of performance outcomes. Idea: This paper relies on the case of OMV Petrom with a view of analysing the evolution of the messages used in framing the success of the company. Data: The letters to shareholders issued by the company from 2005 to 2011 were considered. Tools: A manual content analysis was performed in order to identify the causal attributions of performance outcomes. The enriched self-serving explanatory patterns (i.e. entitlement, enhancement, excuse, justification and causality denial) were evaluated. Findings: The results confirm the use of assertive and defensive tactics in framing performance upturns and downturns. Moreover, the decrease in the financial performance was presented by highlighting the negative influence of external factors which was counterbalanced by remedial actions. Contribution: The paper contributes to the impression management literature by using the context of a forced privatization as a means of providing explanations. The study illustrates the use of additional techniques in framing negative results which may further extend the attributional repertoire developed by previous researchers.
\end{abstract}

\footnotetext{
${ }^{1}$ Corresponding author: Department of Accounting and Auditing, The Bucharest University of Economic Studies, Piața Romană no. 6-8, sector 1, București, Romania. Tel: +4021 319 19 00; email: maria.sandulescu@ cig.ase.ro
} 
Keywords: attribution theory, case study, impression management, letter to shareholders, privatization

\section{JEL codes: $M 41$}

\section{Introduction}

The purpose of this study is to analyse the self-serving use of performance attributions in post-privatization corporate narratives. OMV Petrom is a leader in the Romanian oil and gas industry, its dominant position being also recognized in Southeast Europe. In 2004 the company was the subject of a forced and contested privatization, being involved in several corporate scandals (Lupu \& Sandu, 2017). As a result, this paper aims to focus on the post-privatization narratives in order to assess the evolution of the messages used in framing the success of the company.

The research at hand adopts a social psychology perspective on impression management by making reference to attribution theory. This theory entails the managers' tendency to allocate positive outcomes to internal factors and negative ones to external causes (Hooghiemstra, 2008). The self-serving bias may further result in short-term capital misallocations (Merkl-Davies \& Brennan, 2007). Similarly to many other impression management papers, this concept has been studied mainly in developed economies (Aerts, 2005; Aerts \& Tarca, 2010; Baginski et al., 2000; Lee et al., 2004; Clatworthy \& Jones, 2003). Tarca et al. (2011) acknowledge the differences between each country's institutional setting and their related influence on corporate narratives. However, given the lack of prior papers in the Central and Eastern European (CEE) region, it is currently unclear if there are differences in the use of this opportunistic behaviour in these (or any other) emerging economies. The case of the countries in CEE may be therefore of particular interest since they are in the pursuit of economic development, facing higher growth rates and profitability (Albu \& Albu, 2012). In this context, managers of local and foreign companies acting in emerging economies may exacerbate impression management behaviour.

In this view, I analyse causal explanations of performance outcomes in order to identify potential self-serving biases. Following previous research (Aerts \& Cheng, 2011; Aerts \& Tarca, 2010), explicit and implicit attributions are considered in order to analyse the explained effects, namely the performance outcomes, and the explanatory factors attached. Recent evidence suggests that managers may make use of explanatory statements (Aerts \& Tarca, 2010) to present the accounting information in a manner that can distort the decision making process of the 
stakeholders (Clatworthy \& Jones, 2001, 2006) and thus "encouraging others to see the world in a particular way by making certain aspects of reality more, and others less accessible or noticeable" (Evans \& Pierpoint, 2015: 670). For the purpose of this study, the letters to shareholders issued by Petrom from 2005 to 2011 are used. The period of analysis facilitates the identification of potential changes in the attributional styles that can be the result of "different approaches to managing impressions after performance upturns and downturns" (Lee et al., 2004: 1647).

The paper contributes to the impression management literature by using the context of a forced privatization as a means of providing explanations (Craig \& Amernic, 2004, 2006, 2008). In addition, the study illustrates the use of additional techniques in framing negative results which may further extend the attributional repertoire developed by previous researchers (Aerts \& Cheng, 2011; Aerts \& Tarca, 2010).

The theoretical and research background are introduced in section 2 and 3 respectively. Section 4 sets out the methodology applied in this study. Section 5 presents and discusses the results. The paper concludes in section 6 .

\section{Literature review}

Impression management represents "the process by which people control the impressions others form of them" (Leary \& Kowalski, 1990: 34). In a corporate reporting context, impression management strategies may be used in order to influence stakeholders' perceptions of corporate performance (Merkl-Davies \& Brennan, 2011).

The social-psychology perspective on impression management is rooted in the attribution theory (Merkl-Davies \& Brennan, 2007) that entails the manner in which people explain the causes of events. In corporate narratives, attributional statements illustrate statements where a performance outcome (explained effect) is connected with a cause (explanatory factor) (Aerts, 2005). While companies generally operate in complex environments, the corporate results are under the influence of several internal and external factors. In this view, the attributional statements may be used in a self-serving manner when the causes are selected in the company's own advantage (Merkl-Davies \& Brennan, 2007, Aerts, 2005; Aerts \& Tarca, 2010). As such, previous researchers document the managers' tendency to attribute positive outcomes to internal factors (e.g. managerial decisions, know how, personnel, strategy implementation) and negative ones to external causes (e.g. interest rate, inflation rate, governmental policy, weather) (Aerts, 2005; Hooghiemstra, 2008, Clatworthy \& Jones, 2003, 2006). However, these two types of explanations capture only the basic components of this impression management strategy. 
The extended attributional repertoire distinguishes between assertive and defensive tactics. The assertive explanatory behaviour refers to framing positive events and it includes the use of entitlements and enhancements. While entitlements refer to the attribution of positive outcomes to internal causes, enhancements are used to highlight that positive outcomes were recorded in spite of negative external circumstances (Aerts, 2005; Aerts \& Cheng, 2011; Aerts \& Tarca, 2010; Elsbach \& Sutton, 1992; Hooghiemstra, 2008). In this view, a combination between these two assertive types of explanations is usually reported in the literature (Aerts, 2005; Elsbach \& Sutton, 1992). It has been noticed that organizations make more causal attributions regarding the positive outcomes in order to emphasize or frame a favourable performance while downplaying the existence of negative ones (Hooghiemstra, 2008; Lee et al., 2004). In addition, previous researchers also suggest an inherent tendency of searching and presenting positive outcomes when the overall corporate performance declines (Aerts, 2005; Aerts \& Tarca, 2010, Clatworthy \& Jones, 2003).

The defensive explanatory pattern is associated with the presentation of negative results. An excuse is used when a negative outcome is attributed to an external factor. In addition, the attention of the readers can be shifted away in a self-serving manner (Elsbach \& Sutton, 1992) through the use of justifications. Although this tactic implies the attribution of a negative outcome to an internal factor, it also portrays the event as an intermediary step towards the achievement of other anticipated favourable results. In a similar vein, causality denials can be used to reduce the responsibility for unfavourable results by pointing to the idea that they occurred in spite of internal actions which would have normally led to positive outcomes. Unfortunately, according to Lee et al., defensive tactics can be disserving rather than self-serving. According to the authors, "external and uncontrollable attributions suggest that organizations are unable to control critical outcomes, they violate others' expectations, leading to worse impressions for the organizations." (2004: 1644).

Figure 1 provides an overview of the attributional repertoire used in this study. It illustrates the association between the valence of the outcomes and the self-serving patterns used. 
Self-serving performance attributions in the letters to shareholders: A longitudinal case study

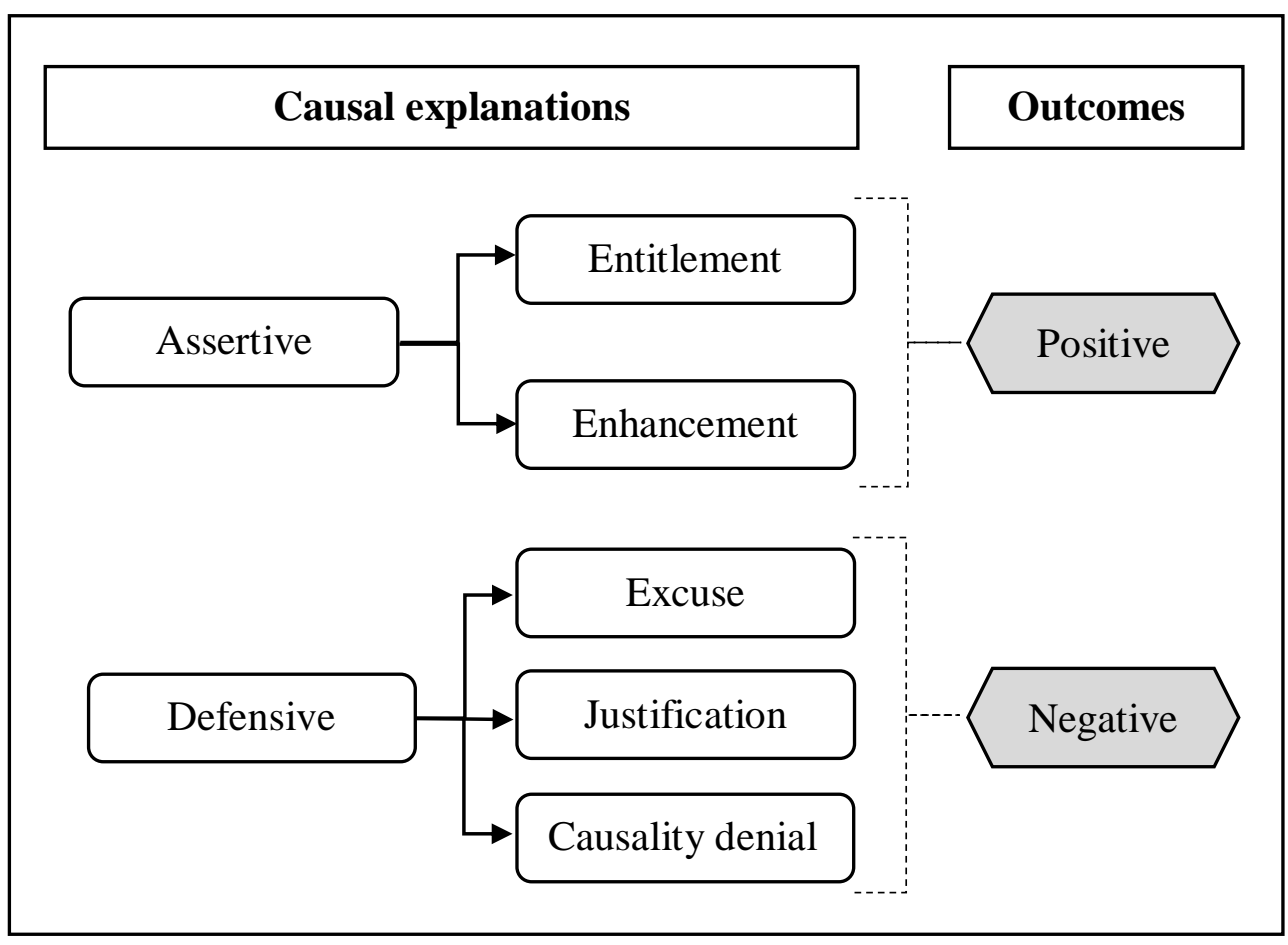

Figure 1. Self-serving attributions and their related association with the valence of performance outcomes

(Source: created by the author following the classification proposed by Aerts and Tarca (2010))

\section{Research background}

Acknowledging that "making sense of events requires that we 'contextualize' them in some way" (Sayer, 1992 cited by Welch et al., 2011: 750) the study analyses the impression management concept in a research background of an emergent economy. An illustrative example is Romania, a country that faced a 50 years exposure period to a socialist ideology, when accounting was perceived as basic bookkeeping and the economic environment was characterized by increased secrecy (Albu et al., 2014a). In 2007 Romania became a European Union (EU) member, with its accounting system being influenced by both the EU Directives and International Financial Reporting Standards (Albu \& Albu, 2012). All these improvements created an economic environment proper for investments (Dumitru et al., 2014). 
However, the economic development of the country was mainly driven by global forces (Albu \& Albu, 2012). In the context of EU accession, the World Bank and the International Monetary Fund requested the privatization of state-owned companies (Lupu \& Sandu, 2017). The way in which this request was implemented in 2004 in the case of Petrom, was characterized by lack of transparency, influenced by political factors, the result being a highly contested privatization (Lupu \& Sandu, 2017). In this respect, media strongly criticized the fact that the consultants contracted by the Romanian State, namely Credit Suisse First Boston, ING and Jacobs Consultancy, underestimated the oil price, which in turn had a negative impact on the value of the oil reserves, lowering the value of the company (Capital, 2006). However, as Adrian Nastase, then Romania's Prime Minister, commented when the contract was signed: "Whoever owns Petrom controls the Romanian economy and whoever dominates the economy can control politics" (Adevărul, 2004). This statement emphasizes the real value of the company and the political interests attached.

Unlike the vast majority of privatized companies from CEE that have undertaken very little restructuring (Filatotchev et al., 2000 cited by Peng, 2003), Petrom began its transition process from a typical state-owned company, influenced by corruption to a private and competitive one. According to Romania's Prime Minister the privatization represented "one of the most important moments in the fight against corruption" (Adevărul, 2004). The supervisory board (7 members) was entirely changed, while the executive board maintained only two members from its previous structure. Starting with 2006 the Chief Executive Officer (CEO) of Petrom is Mariana Gheorghe ${ }^{1}$, the only Romanian member from the executive board.

By implementing OMV's vision, Petrom tried to increase its legitimacy that was negatively impacted by the privatization contract and its unfavourable conditions (Lupu \& Sandu, 2017). In an emerging economy characterized by the lack of transparency (Albu \& Gîrbină, 2015), Petrom differentiated itself from local practices and it became a benchmark in corporate reporting and corporate governance (Albu et al., 2011; Albu et al., 2014b).

The research at hand distinguishes between two reasons that may motivate managers to manipulate the company's investment image. On the one hand, as the company operates in the oil and gas industry, the economic crisis impacted the oil price which in turn was reflected in a downturn in the financial performance. In this line, previous researchers documented the idea that impression management tends to be more pronounced when companies face major predicaments (Aerts, 2005; Merkl-Davies \& Brennan, 2007) as the value of desired goals increases (Leary \& Kowalski 1990; Merkl-Davies \& Brennan, 2007). On the other hand, impression management may spring from "the degree of discrepancy between the image one would like others to hold of oneself and the image one believes others already hold" (Leary \& Kowalski 1990: 39). This impression motivation may be relevant especially when making 
reference to the period following privatization which posits the company in an ongoing struggle to repair the damage of a contested privatization. This motivation may also be relevant for the period following the economic crisis (i.e. from 20092011).

As a result, the paper was designed to evaluate how the company's management explains the upturns and downturns in the financial performance in the years following privatization. A potential laudatory language could have been used to frame the sagacity of the privatization (Craig \& Amernic, 2004) by attributing positive results to internal factors while disregarding the inherent benefits generated by the real value of oil and gas resources.

\section{Research methodology}

In this study, causal explanations of performance outcomes were identified in the annual reports issued by Petrom from 2005 to 2011. It can be noticed that 2005 is the first year following privatization, while 2011 was chosen in order to reflect the subsequent period after the economic crisis. Under Law 297/2004 on capital markets and Regulation no. 1/2006 on issuers and operations with securities, companies have to issue quarterly, half-yearly and annual reports. Hence, only one annual report was issued by Petrom before 2004 (i.e. in 2002), which restrict the period of analysis to the post-privation period.

The documents were gathered from the company's website (www.omvpetrom.com). The English version was considered in order to ensure reproducibility (Krippendorff, 2004).

A manual content analysis was performed. Although its complexity limits the sample size (Brennan et al., 2009), it allows the identification of meanings, unlike a computer-aided method (Krippendorff, 2004).

For the purpose of this study the first procedure used was the identification of attributional statements. According to Aerts (2005: 500) an attributional statement illustrates "a phrase or a sentence in which a corporate event or performance outcome is linked with a reason or a cause for the event or outcome". When an outcome was attributed to several causes, each combination was recorded as a separate statement (Hooghiemstra, 2003). An attribution was explicitly made when connective words like "contributed to", "can be ascribed to", "because of", "as a result of" and "despite" were used (Aerts \& Tarca, 2010; Hooghiemstra, 2008). I also identified attributions that were made implicitly, when a cause-effect relationship was reasonably established (Aerts \& Cheng, 2011). 
The coding procedure further distinguished between explained effects and explanatory factors (Aerts, 2005; Aerts \& Cheng, 2011; Aerts \& Tarca, 2010).

The explained effects were coded according to their valence. Particularly I have analysed whether a positive/negative evolution of the outcome is mentioned. For this dimension the manager's point of view was used.

Similarly, the explanatory factors were coded according to the locus of causality i.e. whether the outcome was caused by internal factors (e.g., managers' decisions, personnel, strategy, know-how, etc.) or external ones (e.g., industry, inflation, interest rate, etc.). Moreover, the direction of the cause - effect relationship was considered. It was coded as identical, when the elements had the same sign and were linked by words such as "due to", or opposite when a positive outcome was accomplished "in spite of" negative conditions.

\section{Results and discussions}

\subsection{Explanations regarding the benefits of the privatization}

The privatization contract signed in December 2004 was highly contested, influenced by political factors (Lupu \& Sandu, 2017). For this reason, the letters to shareholders issued by Petrom in the subsequent period were constantly emphasizing the major benefits of the change in ownership. As such, the modernization process initiated by the company became a persistent topic:

We operate in a very competitive environment, where we wish Petrom to become the best. We've started a far reaching modernization process which aims at the improving of the company's cost and performance position and we will put out all the efforts in order to close the gap to international standards. (Petrom, 2005)

2006 was a remarkable year for Petrom. The projects we implemented focused mostly on modernization, efficiency and profitability increase and on international expansion. (Petrom, 2006)

The increased importance of the transfer of practices from the parent company OMV was also emphasized:

The experience of a strategic investor such as OMV helped us implement rapidly and with excellent results restructuring, centralization and efficiency increase projects in all of our Business Units. (Petrom, 2006) 
As a result, the financial performance was explained by making use of entitlements and hence, with reference to the abovementioned internal factors:

The modernization process, the focused investments and the favorable business environment contributed to the positive financial results in 2005. (Petrom, 2005)

While the company operates in an industry which is highly influenced by the international quotations of crude oil, the "positive" results are firstly attributed to internal factors. As such, "the modernization process" and the "focused investments" become explanatory factors that precede an external one (i.e. "the favourable business environment"). Although the Brent price for crude oil increased by $42 \%$ in 2005 , the order in which the information is presented may indicate a tendency to emphasize internal factors. This may suggest that their influence on performance outcomes was higher.

2006 is the second year in a row in which the company shows a strong performance. This proves our responsible approach, the consistency of our strategy and our determination to reach our objectives. (Petrom, 2006)

Although in 2006 the international quotations for crude oil continued to increase with almost $20 \%$ this external factor is not mentioned in the text. In turn, entitlements are once again used in order to describe the "strong performance" of the company.

\subsection{Explanations regarding the benefits of the privatization in the context of an economic crisis}

Starting with 2007 the financial performance of Petrom followed a declining trend. Particularly, in this year both EBIT and profit figures decreased by $29 \%$ and $22 \%$ respectively. However, the excerpt below incorporates a positive tone, as a negative outcome is framed as being positive using words such as "good" and "above the budget":

In 2007 we made a significant progress in restructuring and modernizing Petrom, and continued to lay the foundations for the sustainable development of the Company. The results we achieved this year are good, being not only above the budget approved by the Shareholders' Meeting, but also achieved during a period of heavy investment efforts. (Petrom, 2007)

At this point, it is worth mentioning that previous literature has documented the existence of attributional enhancements "whereby positive outcomes are portrayed 
within the context of negative external influences, leading to an upgrade of the favorability of the outcome" (Aerts \& Cheng, 2011: 435). However in the above quotation we saw the case of a negative outcome described like a positive one, its "favourability" being enhanced by the context in which it was recorded (i.e. "during a period of heavy investment efforts" - internal factor).

Moreover, for the first time following privatization, the 2007 letter to shareholders includes a description of the economic environment in which the company operates, with a view of highlighting how it negatively impacted corporate results:

The economic environment in 2007 was highly volatile and significantly impacted our operations. High oil prices positively affected our E\&P results, but also led to significant cost inflation in the industry, while the refining margins decreased further. Moreover, the continuous appreciation of the RON against USD during almost all of 2007, also negatively affected our results. (Petrom, 2007)

As it may be noticed, the CEO adopts a defensive stance which may be regarded as biased. Although in 2005 and 2006 both the international quotations for crude oil and the refining margins had an increasing trend, their positive influence on corporate results was highly neglected. In turn, entitlements highlighting the benefits of privatization were used in the presentation of positive outcomes. However, when these two important market drivers had an unfavourable trend, their negative impact on corporate results was particularly emphasized.

Another interesting tactic was further adopted in 2008. Following a brief description of the "general economic and oil-specific downturn", the CEO tried to switch the attention of the reader to the favourable operational performance of the company in order to convey a positive investment image. The attribution of these results to internal factors was also underscored in headings such as "Restructuring and modernization program benefits are more visible":

The benefits of our continuous and consistent restructuring and modernization programs are becoming more and more visible. (Petrom, 2008)

These results were possible due to a considerable investment effort, which rose to reach record levels of over RON 6 bn in 2008, 68\% higher than the previous year, exceeding all our investment obligations stemming from the privatization contract. More importantly, these achievements were the result of the high level of commitment of our employees, supported by the continuous transfer of know-how from OMV Group. (Petrom, 2008) 
As it may be seen, these achievements were introduced to the readers first, in order to alleviate the impact of the decline in the financial performance:

Still, the past year was a year of mixed results as achievements recorded in 2008 were overshadowed by the high level of one-off items booked throughout the year: provisions for litigations and restructuring and the impairment of Arpechim. Moreover, as this situation coincided with the sharp decline of oil prices in the fourth quarter, Petrom's results suffered a significant negative impact, resulting in a $33 \%$ decrease in operating profit for the full year 2008, and a $43 \%$ decrease in net profit respectively, compared to 2007. (Petrom, 2008)

Related thereto, although initially it was clearly stated that the "achievements were the result of the high level of commitment of our employees" the following paragraph brings an opposite perspective, making this assertion questionable. Particularly, the "litigations initiated by former and current employees" had "the largest negative impact on the Company's results".

Among the above mentioned one-off items, the provision Petrom had to book for litigations initiated by former and current employees, conspicuous by its considerable size - RON 1.3 bn - had the largest negative impact on the Company's results. The litigations are based on differing interpretations of several clauses included in Petrom's Collective Bargaining Agreement regarding the granting of some bonuses previously included in the base salary (since 2003). Thus far, Petrom has taken all possible actions and committed all necessary resources to defend against the lawsuits and also to prevent a further increase in litigation.

As the current employees were also involved in these litigations we may therefore "discount" the former causal-effect relationship established between the positive outcomes and the employees. As such, we may conclude that the internal attribution for positive outcomes generally refers to the managerial decisions and the transfer of practices from the parent company, OMV. This view is further transposed in the following excerpt:

We are convinced that our achievements recorded in the four years since privatization, due to our continuous efforts and intensive restructuring and modernization, as well as our solid financial position and low leverage, place us in a good position to face the challenges of a weakening market environment. (Petrom, 2008) 


\subsection{Explanations regarding the management's ability to mitigate external challenges}

Following the economic crisis, the letters to shareholders started to highlight the great ability of the management team in facing the external challenges. In this view, the remedial actions that mitigated the unfavourable impact of the economic environment were underscored. The management team was therefore illustrated as a "hero" in a constant struggle to counterbalance the influence of external forces.

Against this background of reduced demand, the management team was able to make a number of key decisions to mitigate the effects of these challenges while maintaining our strategic directions. (Petrom, 2009)

Lower price levels and volumes decreased our net turnover by $23 \%$. EBIT decreased by $9 \%$ principally due to the unfavorable oil price environment and weak refining margins. This was partly offset by our cost reduction measures. (Petrom, 2009)

First and foremost, 2010 was an important milestone in Petrom's strategic path towards becoming a leading integrated energy player in Southeastern Europe. It was also a proof of management's ability to adapt and successfully steer the company through challenging market conditions. (Petrom, 2010)

This image was further portrayed by means of entitlements and enhancements, illustrating a "romance of leadership" bias as documented by Meindl and Ehrlich (1987):

Our net profit was positively impacted by our decision to hedge against oil prices fluctuations (hedging gain of RON $524 \mathrm{mn}$ ) and increased by $34 \%$ to RON 1,368 mn. (Petrom, 2009)

In Exploration and Production, we made some significant improvements despite the challenging environment. (Petrom, 2009)

Moreover, our focus on streamlining operations and strict cost management enabled us to deliver a strong set of results, in spite of a weak economic environment. (Petrom, 2010)

Although EBIT in Refining and Marketing remained negative, we improved it to RON (828) mn from RON $(1,895) \mathrm{mn}$ in 2008 , despite depressed refining margins. This was achieved through continuing improvements in marketing and optimizing refinery utilization. (Petrom, 2009) 
It is worth mentioning that 2009 is the first year in which the manager mentions the EBIT recorded in the Refining and Marketing (R\&M) segment in order to indicate an improvement "despite depressed refining margins". As the company explains in its annual report, the refining margin "is based on the international quotations for products (Augusta) and Urals crude and a standardized yield set typical for Petrom's refineries" (Petrom, 2009: 34). Consequently, this operating result was concealed in the previous years since its value was negative and its evolution was unfavourable (Merkl-Davies \& Brennan, 2007; Leung et al., 2015). Assertive tactics were also used in the following years with reference to this result:

In Refining and Marketing, the economic downturn affected our fuels sales and burdened our margins. Nonetheless, we managed to significantly improve the R\&M clean CCS EBIT by more than RON $500 \mathrm{mn}$, due to structural improvements and optimized operations, with the Arpechim refinery remaining in economic shutdown for most of the period. (Petrom, 2010)

Supported by improved underlying operational performance in refining, 2011 was the first year after privatization with a positive clean CCS operational result in R\&M. (Petrom, 2011)

However, as the financial performance of the company started to improve, the corporate narratives also included references to the positive impact of the favourable crude price environment. Nevertheless, it may be observed how this external factor is always accompanied by an internal one:

Over this background of weakening market conditions in our operating region, our strong financial results reflect the effectiveness of optimization initiatives and a favourable crude price environment. (Petrom, 2010)

EBIT adjusted for special items and inventory holding effects (clean CCS EBIT) increased 65\% over the previous year to reach RON 5.5 bn, driven by improved operating performance and the favorable crude price environment. (Petrom, 2011)

We look back at 2011 as a year of outstanding operational performance and strong financial results for Petrom, albeit with some external challenges. This was a result of high investment efforts, effective cost and operational management but also supportive crude prices. With the great commitment of our employees, we continued to deliver on our strategic direction of leveraging Petrom's integrated business model as a key element to value creation. (Petrom, 2011) 
Although the last excerpt includes an acknowledgement for the "great commitment of our employees" the link between the performance outcomes and the employees is not made (Merkl-Davies \& Koller, 2012). Furthermore, it can be regarded as "ironic that employees are being thanked by the chairman for their 'tremendous effort'... in a year of drastic redundancies" (Merkl-Davies \& Koller, 2012: 187). Particularly in 2011 the number of employees was 54\% lower than in 2004 following a year on year decrease.

This study illustrated the evolution of the messages used by the CEO in framing the financial performance of the company. These messages need to be interpreted considering the context in which they were written. Following privatization, OMV adopted the strategy of deploying expatriates as executive managers in order to facilitate the implementation of its vision (Peng, 2003). Acknowledging the idea that "firms need both relational and competitive assets in order to survive and prosper" (Peng, 2003: 290) the CEO position was allocated to the only Romanian member of the Board (i.e., starting with 2006, Mariana Gheorghe). As the media supported the idea that the Austrian company "gained control over the most important company in the Romanian economy, paying the state only one third of its value" (HotNews.ro, 2004), a Romanian CEO was the perfect solution to alleviate the tensions created. While Goffman (1959) explains impression management using the metaphor of individuals as actors performing on a stage in front of an audience, the Romanian CEO may be considered as the right actor to perform on the stage of a contested privatization.

As resulting from the company's letters to shareholders, Petrom's subsequent positive performance was attributed to the restructuring and modernization process, downplaying the major increase of the international quotations for crude oil. In contrast, during the economic crisis, the negative impact of the steep decrease of oil prices was emphasized. Moreover, the letter attempted to put a positive spin on events (Suchman, 1995 cited by Aerts \& Cheng, 2011), by pointing to the achievements recorded as a result of the restructuring and modernization programs. Last but not least, a "romance of leadership" bias manifested in the period following the economic crisis (Meindl \& Ehrlich, 1987), as the performance outcomes were attributed to the management team. This further highlighted the benefits associated with the implementation of OMV's vision.

\section{Conclusions}

This case study focused on the use of attributional biases in the context of a privatized company which faced performance upturns and downturns. On the one hand, the results are consistent with previous findings on the self-serving use of assertive tactics in the presentation of positive outcomes (Aerts, 2005; Aerts \& Cheng, 2011; Aerts \& Tarca, 2010; Clatworthy \& Jones, 2003; Merkl-Davies \& 
Brennan, 2007). On the other hand, the downturn in the financial performance was illustrated through the use of excuses, complemented by the managerial tendency of switching the perspective of the reader by pointing to other achievements (Aerts, 2005; Aerts \& Cheng, 2011). However, the study did not provided evidence on the use of justifications and causality denials (Aerts, 2005; Aerts \& Cheng, 2011; Aerts $\&$ Tarca, 2010). In turn, the decrease in the financial performance was presented by highlighting the negative influence of external factors which was counterbalanced by remedial actions. Moreover, another technique used was to alter the valence of an outcome. Particularly, although the corporate results followed a decreasing trend, they were framed in a positive tone while also pointing to negative external influences.

This paper may be useful for researchers, who wish to have a better understanding of impression management by providing insights from the case of an emerging economy, in a research background focused on the case of developed markets. In addition, the study provides evidence that is relevant for investors who should envisage potential self-serving practices in corporate narratives disseminated by companies. Last but not least, accounting policy-makers and professional bodies should acknowledge the impact of this opportunistic behaviour that can eventually lead to capital misallocations (Merkl-Davies \& Brennan, 2007).

Future research may further address the case of a stigmatized company because previous literature that followed Erving Goffman's studies, (Evans \& Pierpoint, 2015; Sutton \& Callahan, 1987) emphasized a connection between impression management and stigma management. Moreover, the potential impact of biased causal attributions on users of the accounting information can be explored in an experimental setting.

\section{Notes}

1. On January 9, 2018 the Supervisory Board of OMV Petrom S.A. appointed Christina Verchere, a former executive at British Petroleum, as the new CEO of the company.

\section{Acknowledgements}

A special thank you to Cătălin Albu, Sebastian Hoffmann, Anna Alon and Andrei Filip for the time and attention they gave this paper to its advantage. I also acknowledge the thoughtful and insightful suggestions provided by the editor in chief of the Journal (Nadia Albu) throughout the revision process. Previous versions of this paper have been presented at the 2017 IAAER ACCA Central and Eastern European Emerging Accounting Scholars Research Workshop in Bucharest, the 2017 International Accounting Symposium in Madrid, the 2017 IAAER CIMA Paper Development Workshop in Krakow, the 2018 International Conference 
Accounting and Management Information Systems in Bucharest and at the 2018 International Conference IFRS: Global Rules and Local Use in Prague. This paper was co-financed by The Bucharest University of Economic Studies during my $\mathrm{PhD}$ program.

\section{References}

Adevărul (2004), „'Cine conduce Petrom controleaza economia romaneasca si poate controla si politica"' ['Whoever owns Petrom controls the Romanian economy and can control politics'], Adevărul, 24 July, available on-line at https://adevarul.ro/news/societate/cine-conduce-petrom-controleazaeconomia-romaneasca-controla-politica1_50abe7707c42d5a6638223f5/index.html (Accessed 27 February 2018).

Aerts, W. (2005) „Picking up the pieces: Impression management in the retrospective attributional framing of accounting outcomes", Accounting, Organizations and Society, vol. 30, no. 6: 493-517.

Aerts, W. \& Cheng, P. (2011) „Causal disclosures on earnings and earnings management in an IPO setting", Journal of Accounting and Public Policy, vol. 30, no. 5: 431-459.

Aerts, W. \& Tarca, A. (2010) „Financial performance explanations and institutional setting", Accounting and Business Research, vol. 40, no. 5: 421-450.

Albu, C. N., Albu, N. \& Alexander, D. (2014a) „When global accounting standards meet the local context- Insights from an emerging economy", Critical Perspectives on Accounting, vol. 25, no. 6: 489-510.

Albu, C. N. \& Gîrbină, M. M. (2015) „Compliance with corporate governance codes in emerging economies. How do Romanian listed companies 'comply-orexplain'?", Corporate Governance: The International Journal of Business in Society, vol. 15 , no. 1: 85-107.

Albu, N. \& Albu, C.N. (2012) „International Financial Reporting Standards in an emerging economy: Lessons from Romania", Australian Accounting Review, vol. 22, no. 4: 341-352.

Albu, N., Albu, C. N., Bunea, Ş., Calu, A. D. \& Gîrbină, M. M. (2011) „A story about IAS/IFRS implementation in Romania", Journal of Accounting in Emerging Economies, vol. 1, no. 1: 76-100.

Albu, N., Lupu, I. \& Sandu, R. (2014b) „Multinationals as vectors of corporate governance improvement in emerging economies in Eastern Europe: A case study", in Boubaker, S. and Nguyen, D. K. (Eds.), Corporate Governance in Emerging Markets. CSR, Sustainability, Ethics \& Governance, pp. 331-349, Springer-Verlag Berlin Heidelberg.

Baginski, S. P., Hassell, J. M. \& Hillison, W. A. (2000) „Voluntary causal disclosures: Tendencies and capital market reaction", Review of Quantitative Finance and Accounting, vol. 15, no. 4: 371-389. 
Brennan, N.M., Guillamon-Saorin, E. \& Pierce, A. (2009) „Impression management: Developing and illustrating a scheme of analysis for narrative disclosures - A methodological note", Accounting, Auditing \& Accountability Journal, vol. 22, no. 5: 789-832.

Capital (2006) „Petrom, vânzare la jumătate de preț” [Petrom, sale at half price], Capital, 22 June, available on-line at https://www.hotnews.ro/stiri-arhiva1172119-petrom-vanzare-jumatate-pret.htm (Accessed 27 February 2018).

Clatworthy, M.A. \& Jones, M.J. (2001) „The effect of thematic structure on the variability of annual report readability", Accounting, Auditing \& Accountability Journal, vol. 14, no. 3: 311-326.

Clatworthy, M.A. \& Jones, M.J. (2003) „Financial reporting of good news and bad news: Evidence from accounting narratives", Accounting and Business Research, vol. 33, no. 3: 171-185.

Clatworthy, M.A. \& Jones, M.J. (2006) „Differential patterns of textual characteristics and company performance in the chairman's statement", Accounting, Auditing \& Accountability Journal, vol. 19, no. 4: 493-511.

Craig, R. \& Amernic, J. (2004) „The deployment of accounting-related rhetoric in the prelude to a privatization", Accounting, Auditing \& Accountability Journal, vol. 17, no. 1: 41-58.

Craig, R. \& Amernic, J. (2006) „The mobilization of accounting in preening for privatization", Accounting, Auditing \& Accountability Journal, vol. 19, no. 1: 82-95.

Craig, R. \& Amernic, J. (2008) „A privatization success story: Accounting and narrative expression over time", Accounting, Auditing \& Accountability Journal, vol. 21, no. 8: 1085-1115.

Dumitru, M., Albu, N., Dumitru, V. \& Albu, C.N. (2014) „Practices regarding the forms of communication with the consumers used by a multinational company at global and local level", Amfiteatru Economic, vol. 16, no. 35: 41-57.

Elsbach, K.D. \& Sutton, R.I. (1992) „Acquiring organizational legitimacy through illegitimate actions: A marriage of institutional and impression management theories", Academy of Management Journal, vol. 35, no. 4: 699-738.

Evans, L. \& Pierpoint, J. (2015) „Framing the Magdalen: Sentimental narratives and impression management in charity annual reporting", Accounting and Business Research, vol. 45, no. 6-7: 661-690.

Goffman, E. (1959). The presentation of self in everyday life, New York: Doubleday Anchor Books.

Hooghiemstra, R. (2003) The Construction of Reality: Cultural differences in selfserving behaviour in accounting narratives, Rotterdam: ERIM Ph.D. Series Research in Management.

Hooghiemstra， R. (2008) „East-West differences in attributions for company performance: A content analysis of Japanese and US corporate annual reports", Journal of Cross-Cultural Psychology, vol. 39, no. 5: 618-629.

HotNews.ro (2004) „Petrom a devenit proprietatea austriecilor de la OMV” [Petrom became the property of the Austrian OMV], HotNews.ro, 24 July, available 
on-line at https://www.hotnews.ro/stiri-arhiva-1262225-petrom-devenitproprietatea-austriecilor-omv.htm (Accessed 27 February 2018).

Krippendorff, K. (2004). Content analysis. An introduction to its methodology, $2^{\text {nd }}$ ed., Thousand Oaks: Sage.

Leary, M.R. \& Kowalski, R.M. (1990) „Impression management: A literature review and two-component model", Psychological Bulletin, vol. 107, no. 1: 34-47.

Lee, F., Peterson, C. \& Tiedens, L.Z. (2004) „Mea culpa: Predicting stock prices from organizational attributions", Personality and Social Psychology Bulletin, vol. 30, no. 12: 1636-1649.

Leung, S., Parker, L. \& Courtis, J. (2015) „Impression management through minimal narrative disclosure in annual reports", The British Accounting Review, vol. 47, no. 3: 275-289.

Lupu, I. \& Sandu, R. (2017) „Intertextuality in corporate narratives: A discursive analysis of a contested privatization", Accounting Auditing \& Accountability Journal, vol. 30, no. 3: 534-564.

Meindl, J.R. \& Ehrlich, S.B. (1987), „The romance of leadership and the evaluation of organizational performance", Academy of Management Journal, vol. 30, no. 1: 91-109.

Merkl-Davies, D.M. \& Brennan, N.M. (2007) „Discretionary disclosure strategies in corporate narratives: Incremental information or impression management?", Journal of Accounting Literature, vol. 26, no. 1: 116-194.

Merkl-Davies, D.M. \& Brennan, N.M. (2011) „A conceptual framework of impression management: new insights from psychology, sociology and critical perspectives", Accounting and Business Research, vol. 41, no. 5: 415-437.

Merkl-Davies, D.M. \& Koller, V. (2012) „'Metaphoring' people out of this world: A Critical Discourse Analysis of a chairman's statement of a UK defence firm", Accounting Forum, vol. 36, no. 3: 178-193.

Peng, M.W. (2003) „Institutional transitions and strategic choices”, Academy of Management Review, vol. 28, no. 2: 275-296.

Petrom (2005) 2005 Annual Report, available on-line at https://www.omvpetrom. com/pbd_download/688/967/Petrom_Annual_Report_2005_en,0.pdf (Accessed 27 February 2018).

Petrom (2006) 2006 Annual Report, available on-line at https://www.omvpetrom. com/pbd_download/911/18/Petrom_Annual_Report_2006_en,0.pdf (Accessed 27 February 2018).

Petrom (2007) 2007 Annual Report, available on-line at https://www.omvpetrom .com/pbd_download/700/563/Annual_Report_2007_en.pdf (Accessed 27 February 2018).

Petrom (2008) 2008 Annual Report, available on-line at https://www.omvpetrom. com/pbd_download/333/169/Petrom_Annual_Report_2008_en.pdf (Accessed 27 February 2018). 
Petrom (2009) 2009 Annual Report, available on-line at https://www.omvpetrom. com/pbd_download/556/244/Petrom_Annual_Report_2009_en,1.pdf (Accessed 27 February 2018).

Petrom (2010) 2010 Annual Report, available on-line at https://www.omvpetrom. com/pbd_download/502/877/Petrom_Group_Annual_Report_2010_en.pdf (Accessed 27 February 2018).

Petrom (2011) 2011 Annual Report, available on-line at https://www.omvpetrom. com/pbd_download/738/733/08_Annual_Report_Petrom_Group_2011_en.p df (Accessed 27 February 2018).

Rutherford, B. A. (2005) „Genre analysis of corporate annual report narratives: A corpus linguistics-based approach”, Journal of Business Communication, vol. 42, no. 4: 349-378.

Sutton, R. I. \& Callahan, A. L. (1987) „The stigma of bankruptcy: Spoiled organizational image and its management", The Academy of Management Journal, vol. 30, no. 3: 405-436.

Tarca, A., Street, D.L. \& Aerts, W. (2011) „Factors affecting MD\&A disclosures by SEC registrants: Views of practitioners", Journal of International Accounting, Auditing and Taxation, vol. 20, no. 1: 45-59.

Welch, C., Piekkari, R., Plakoyiannaki, E. \& Paavilainen-Mäntymäki, E. (2011) „Theorising from case studies: Towards a pluralist future for international business research", Journal of International Business Studies, vol. 42, no. 5: 740-762. 